\title{
EXPERIENCES OF PARTICIPANTS IN ON-THE-JOB TRAININGS IN BORSOD-ABAÚJ-ZEMPLÉN COUNTY
}

\author{
Barbara Le-Dai' ${ }^{1}$, Dávid Hajdú ${ }^{2}$ \\ ${ }^{1}$ Hungarian University of Agriculture and Life Sciences \\ 2Hungarian University of Agriculture and Life Sciences Doctoral School of Economic and Regional Sciences
}

One of the most important fringe benefits for employers is education. Employees who have been trained are more attached to the company and their esteem increases. The survey interviewed 371 employees of enterprises participating in the GINOP (Economic Development and Innovation Operational Programme of Hungary) 6.1.5-17 "Support for on-the-job training for large enterprises" and GINOP-6.1.6-17 "Support for on-the-job training for micro, small and medium-sized enterprises". The interviewees had different positions and educational qualifications. It could be shown that those who had been trained were able to use the new skills, some of them leading to an increase in income. The biggest risk of on-the-job training is that the workforce trained by the company is seduced by a competing company, resulting in a huge loss for the company.

Keywords: human resources, adult training, on-the-job training, training

\section{Introduction}

One of the most important tasks in the years after the Global Financial Crisis 2007-2008 (GFC) was to reform the whole society, to improve people's access to work, with the ultimate goal of creating a work-based society in Hungary (Kárpáti-Daróczi, 2020). As a result of these efforts, actors entered the labor market in 2010 with the introduction of new types of active labor market instruments who did not have a job before the crisis (Novoszath, 2018). Success also involved increasing the sense of individual responsibility and ownership. Part of a work-based society is the individual's own intellectual development and well-being, he or she must create opportunities and take action for his or her own development, and the state's role is to provide the basic necessities for this (Horváth, 2018). The aim of this study is to highlight the positive and negative effects of on-the-job training and to make it as useful as possible for employees and the companies.

Choosing and training the right profession is not a task for the state, but it can help this segment to flourish by integrating it into the system with the means and resources at its disposal (Berg, 2015). It is also in the interest of the state, because if future workers have the opportunity to learn a profession that suits their interests and individual preferences and can later find a job in this profession, they will also help the economy to flourish, because they will be better taxpayers and producers for society by working in a position that suits them (Petty and Thomas, 2014). These working-age people will generally lead happier lives if they are in the right position, will be more satisfied with their lives than their destitute counterparts who have not received any help in choosing and following the right career orientation, will be less sick and will spend less time outside the labour market (Hirschi, 2011). With this ability and opportunity, they can also be successful in their private lives, as they can create a safe environment for their children and are more likely to be able to help their older relatives, thus taking the burden off the state (Kiss and Pirohov-Tóth, 2020).

In the past, the possibility of choosing a career was opened up to those who went to vocational training or vocational schools around the age of 14 , when they left primary school. Those who chose upper secondary school had to choose a career until the age of 18 . Assistance with career choice is primarily the responsibility of parents and teachers, especially class teachers, but it is now possible to attend career guidance counselling, which can be of great help for those who are more indecisive (Borbély-Pecze and Fazakas, 2017, 2019). Young people who drop out of education earlier will find it harder to perform in education later in their studies (Karlovitz and Micheller, 2007).

One of the key players in adult learning is the employer. His/her role is fundamental, since he/she is the initiator, promoter and even the place provider, or at least the tolerator, of a large part of adult learning. The motivations for employers' behaviour are also well known from the standard literature on the economics of education (Varga, 1998). Employers' attitudes towards the training of their employees differ depending on whether it is general or specific training. Training is general if it increases the productivity of the participants in a way that is not only effective in the firm providing the training, but also in other firms. Specific training is a training where the productivity gains it generates are only achieved in the enterprise paying the training. General training is only 'subsidised' (i.e. tolerated) by the employer if the costs of the training are not paid by the employer. However, training participants are willing to pay the costs of training because it increases their future earnings (Márkus, 2016). In the case of specific training, on the other hand, the employer shares part of both the costs and benefits of the training with the employee. In the case of specific training, the employer should pay the full cost of the training (Polónyi,2004). However, if he/she pays all the training costs, he/she will have to pay them if the employee changes jobs in the future, which is not useful for him/her. Therefore, the employer acts reasonably by sharing both the training costs and part of the benefits with the employee. In other words, he/she is willing to bear part of the training costs but is not willing to pay a full wage increase that does not correspond to the productivity increase (Farkas, 2014). Finally, an economic theory suggests that the willingness of employers to bear the costs is rather limited, to the extent that they are not willing to bear the costs of training for general training and only partially for specific training (Polónyi,2004).

Matiscsákné Lizák (2012) distinguishes between induction programmes, skills development programmes, vocational training, leadership training, and career programmes based on the content of workplace training. Through competence development, workplace training also contributes 
to organisational goals such as improving quality, increasing productivity, preparing for the introduction of new technology, increasing organisational flexibility, increasing job satisfaction, or transforming organisational culture (Vaszari, 2016).

According to Vámosi (2005), training is a tool for human resource development - it is concerned with improving the skills of workers and their ability to meet the ever-changing demands of the workplace. By providing new skills, it can help workers to take on additional responsibilities and jobs, and to learn new professions. Goldstein and Ford (2002), on the other hand, take a more performance-oriented approach: training is one of the most widely used methods to enhance individual performance and to stimulate work performance in the workplace. Farjad (2012) defines training as an ongoing activity in which, through a variety of methods, existing and new services are provided to employees to develop or deepen the skills they need or will need to do their jobs.

\section{Material and methods}

As a basis for the primary research, we conducted a questionnaire survey after having studied the available domestic and international textbooks and journal articles on the topic. The questionnaire survey was personally supervised. Around 500 people were recruited by the survey companies, out of which 371 were interviewed. All respondents were employed by the enterprises. The collected database was processed and evaluated using Microsoft Office 2013 and IBM SPSS Statistics 20. The training courses ran from December 2018 to December 2020. The questionnaire survey was conducted 6 months after the training courses were completed. The enterprises where the survey took place are all operating in the county of Borsod-Abaúj-Zemplén, and all their employees live in this county. Overall, employees had a say in what training they wanted to attend, but it was largely their supervisors who suggested it, as well as the participants.

The two calls examined are GINOP (Economic Development and Innovation Operational Programme)-6.1.5-17 Support for on-the-job training for large enterprises and GINOP-6.1.6-17 Support for on-the-job training for micro, small and medium-sized enterprises. The main objective of both calls is to strengthen the idea of lifelong learning and to overcome the disadvantages caused by a lack of knowledge or skills linked to changes in society and the labour market. The conditions for participation in the application include that only low-income workers, i.e. workers whose gross wage did not exceed HUF 405,459 on average in the 6 months preceding the training, are eligible to participate in the training. Participants in training courses were determined by their gross salary, from which the beneficiary could deviate by $10 \%$. That is, if there were 20 participants whose gross monthly wage did not exceed HUF 405,459 on average over the last 6 months, in that case two participants could be employees whose gross wage was up to HUF 600,000 . For large companies, the same rule applies, except that $10 \%$ of the employees involved may not have a gross wage exceeding HUF 600,000 . In the case of large companies, the applicant must involve in the training participants outside the company who are temporarily unemployed (and were public employee up to 12 months before) at the time of the training, up to a minimum of $10 \%$ of its own workforce. Within the framework of the GINOP-6.1.6-17 project, the involvement of external participants is possible, but not mandatory. External participants can only be publicly employed, job seekers or inactive persons during the time pot of involvement. This also obliges large companies to engage in social participation. The types of trainings eligible for support were:
$\square$ external training,
$\square$ internal training,
$\square$ or in the context of self-delivered training.

Only the beneficiary's own employees may be involved in internal training. At least $80 \%$ of the training (the basis here is the total number of planned training hours) must be external and/or internal training. The training may take the form of:

$\square$ distance learning,

$\square$ individual coaching,

$\square$ group training.

Eligible training programmes may be:

$\square$ Training included in the National Training Register (hereinafter: OKJ) (on the basis of Act LXXVII of 2013 on Adult Education (hereinafter referred to as the "Fktv."), these training courses cannot be implemented as internal training.

$\square$ (ombined (including specialist language) or other language training (under the Fktv.).

$\square$ Other vocational training (under the Fktv.).

$\square$ Other training (under the Fktv.).

$\square$ Training not covered by the Act.

With the exception of training courses not covered by the National Training Register (OKJ) and the Fktv., all training courses must be simultaneously video-recorded with audio recording, or audio material and hourly photographic documentation must be produced, with metadata being made available. This must be agreed in writing by the participants in order to avoid violation of the GDPR law. Up to $15 \%$ of eligible training may be other or combined language training. The percentage is based on the total number of planned training hours. As regards the delivery of the training, it is compulsory for the training to be carried out at the beneficiary's own headquarters or premises, except where this is not possible (for example, in the case of training courses for the Master of Vocational Qualifications, where the training cannot be carried out at the

Table 1 A comparison of the more precise parameters of the proposals examined

\begin{tabular}{|l|c|c|}
\hline & GINOP-6.1.5-17 & GINOP-6.1.6-17 \\
\hline Amount of aid available [HUF] & $10,000,000-100,000,000$ & $3,000,000-50,000,000$ \\
\hline maximum gross salary of eligible workers & HUF 405,459 & HUF 405,459, up to $10 \%$ of employees HUF 600,000 \\
\hline the involvement of external persons & it is possible, but not compulsory & must have at least 10\% of its own staff, but at least 2 employees \\
\hline available resource & HUF 12,640,000,000 & HUF 7,527,000,000 \\
\hline number of participants in training & minimum 3 persons & minimum 17 employees, minimum 15 employees
\end{tabular}

Source: GINOP-6.1.5-17 and GINOP-6.1.6-17 calls for proposals (https://www.palyazat.gov.hu/ginop-615-17-munkahelyi-kpzsek-tmogatsa-nagyvllalatok-munkavllali-szmra; https://www.palyazat.gov.hu/ginop-616-17-munkahelyi-kpzsek-tmogatsa-mikro-kis-s-kzpvllalatok-munkavllali-szmra) 
premises provided by the beneficiary, in which case it can be carried out at another location after an application has been submitted). The minimum number of hours for all training courses supported is 20 hours. The Széchenyi 2020 logo and, where possible, the project ID and name must be included on all related documents of the training. The maximum amount of funding per participant in the project is HUF 580,000 per person. A person may participate in more than one training course, but the maximum amount of support that may be requested remains the same. For each training course, the maximum permitted absence rate is $10 \%$ of the number of hours of the training course, if the training programme specifies a stricter attendance rate, this will be the determining factor.

\section{Results and discussion}

The majority (77.6\%) of the workers enrolled in training (371 participants) were men and manual workers, with women working mostly in clerical jobs. The youngest worker in training was 26 years old and the oldest one 66 years old, with an average age of 48.4 years. Most participants had a school leaving certificate and vocational education. Only $19.4 \%$ of the respondents had tertiary education. The smallest group (2.9\%) were people with primary education (Figure 1). Employers were most likely to train those with graduation or vocational education. There were three workers in the sample who had increased their educational attainment from primary to vocational education during training.

The types of training can be divided into 5 groups: vocational training, language training, training for public authorities, IT training and training courses (self-awareness training, sensitivity training, conflict management training, personal development training, in other words, any training that does not give you professional, language and IT skills), as listed in the National Training Register. The largest proportion of employers chose training courses to train their existing employees. A similar level of enrolment was observed in the OKJ training courses. Employers wanted to fill jobs where they could not recruit new workers with their existing workforce. These advertised vacancies are mostly in shortage occupations. Employers can reallocate the existing workforce to these areas through internal and external training, but learning a new qualification can increase the labour market position of the worker. The lowest level of enrolment was in language training, which is due to the fact that the number of hours of language training in the project training courses did not exceed $15 \%$ of the total number of hours, which is also the reason for the low presence of language training (Figure 2).

Most of them (50.4\%) felt that their esteem at work had increased, $36.9 \%$ felt that they had consolidated their job in terms of participation in training, they felt more confident that they would not be affected in case of turnover in the future. However, there were also some workers for whom participation in training had a negative impact. Many of them found it a nuisance, did not acquire new skills, and found it difficult to carry out their daily work (Figure 3).

$95.6 \%$ of workers were able to use the new knowledge in their daily work, only $4.4 \%$ thought they had not acquired knowledge that would have had a positive impact on their work. As mentioned above, employees had a say in what training they wanted to attend, but it was up to their line manager to decide. This may be due to the fact that managers are not so familiar with the employee's professional knowledge. The $86.5 \%$ of respondents had attended training courses that they wanted to. This is a very good situation for both employer and employee, as employee needs have been met to a greater extent, which should have a positive impact on the life of the company. Direct managerial decisions have influenced participation in training, with $13.5 \%$ of employees not attending the training they would have liked to (Figure 4).

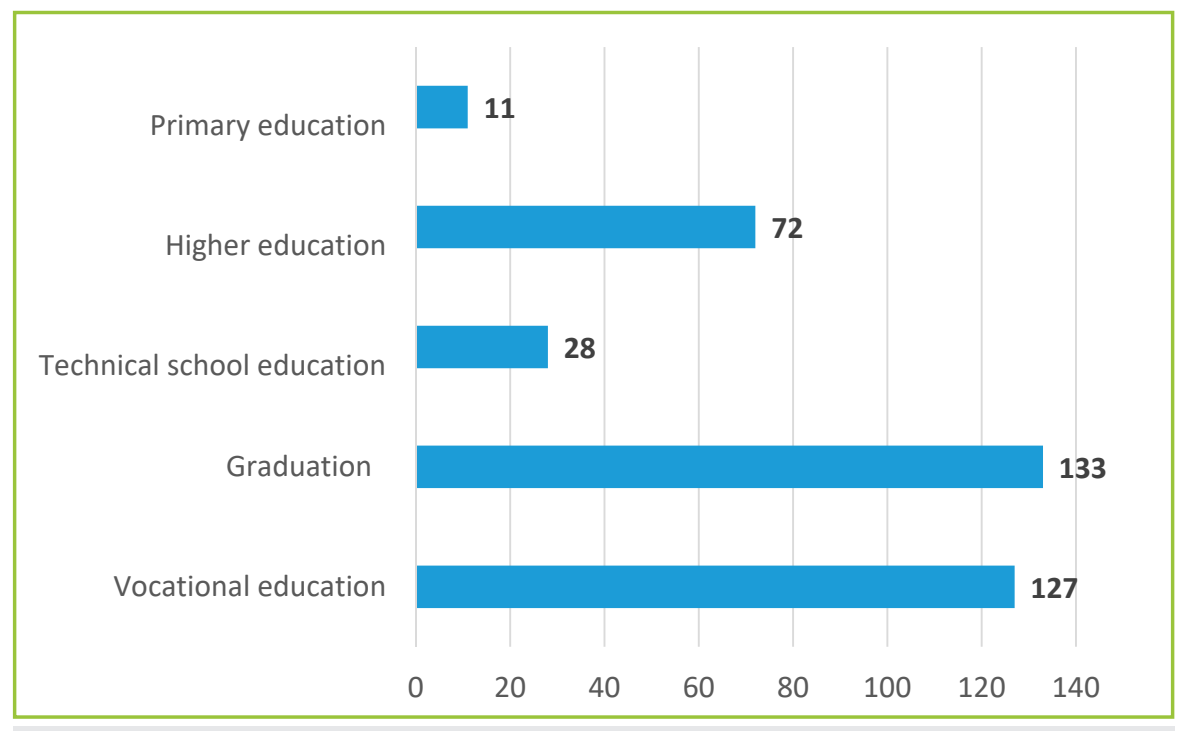

Figure 1 Distribution of highest educational attainment in the sample

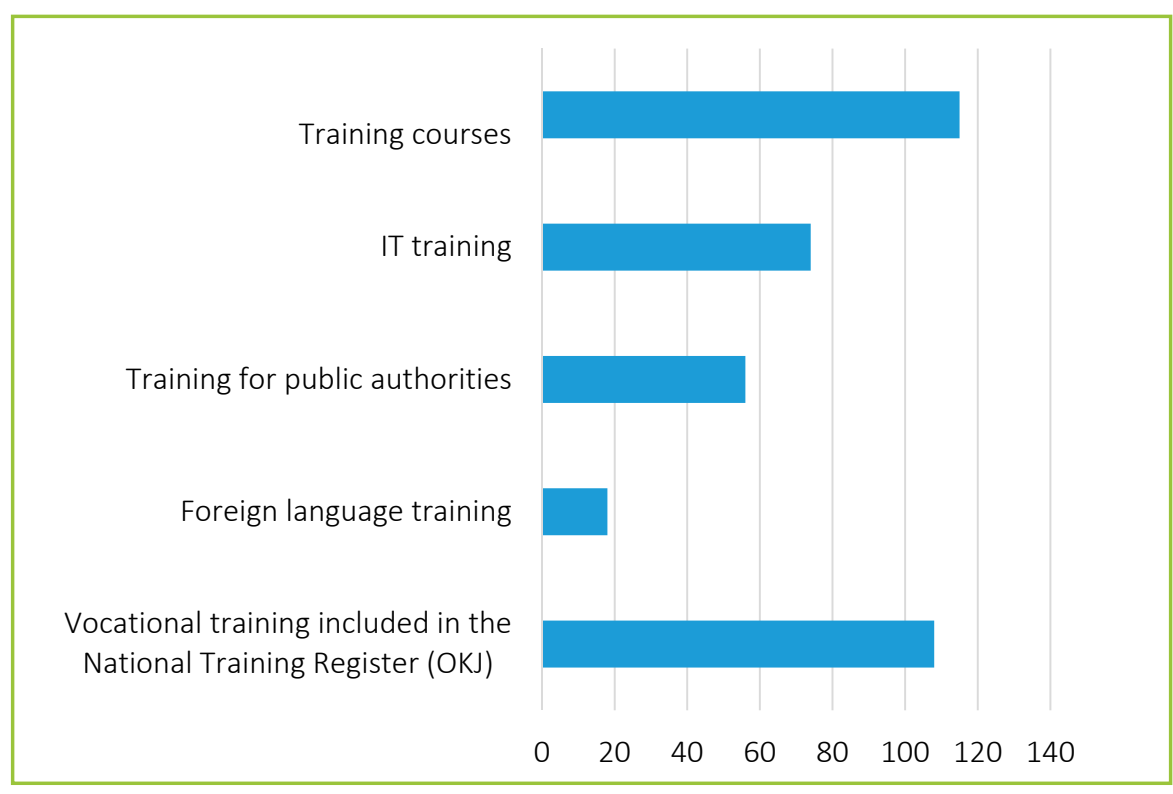

Figure 2 The proportion of training participants by type of training 


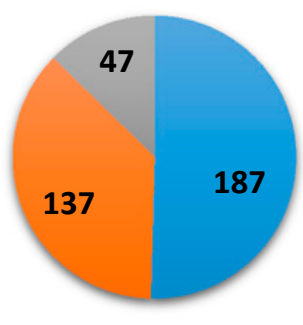

My esteem at work has grown

My workplace has solidified

It was a fuss for me, making it difficult to work everyday

Figure 3 Resonance of training among respondents

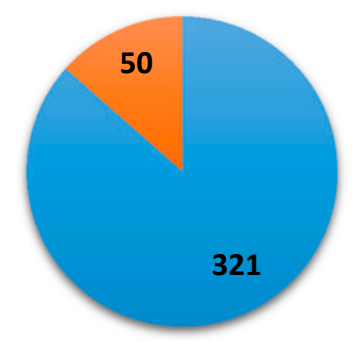

I took part in the trainings I wanted to

I didn't attend the trainings I wanted to

Figure 4 Participation in trainings according to the wishes of the participants

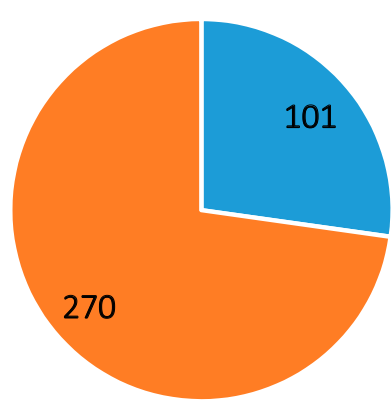

My income has increased

- My income has not changed

Figure 5 Changes in income after completing training

One of the most important factors for workers, apart from working conditions and employer appreciation, is monthly income. After completing the training, employees have gained new knowledge and skills, which can lead to their integration into new work processes and more accurate work for the employer, thus indirectly contributing to the value of the company. More than a quarter (27.2\%) of workers who had received training increased their monthly income after completing the training. This has further increased their loyalty to the company (Figure 5).
Some of the workers who have successfully completed the training have changed position, but only those who had attended a vocational training course with an $0 \mathrm{KJ}$ were the ones who changed jobs. $4.3 \%$ of respondents received a new job offer with their newly acquired qualification.

\section{Cross-tabulation analyses}

More male managers were trained by employer sponsorship than female managers in terms of their position in the workplace, but a higher proportion of women (21.68\%) than men (13.54\%) were in managerial positions compared to the gender ratio of respondents. $86.4 \%$ of men and $78.3 \%$ of women who had a job were in a managerial position. In terms of highest educational attainment, $2.1 \%$ of respondents (8) had primary education, of which only 1 was female in the sample. $35 \%$ had vocational education, with the highest percentage (35.8\%) indicating A-levels as the highest level of education. The proportion of those with technical education was low at 7.5\%, but the proportion with tertiary education was high at $19.4 \%$. The proportion of those with at least a college degree differed by gender, with $42.2 \%$ of women and $12.8 \%$ of men having this highest level of education. In terms of educational attainment, most of the managers were graduates from tertiary education, but $19.3 \%$ had a school leaving certificate.

In adult education in Hungary, learners can study foreign languages, professions, IT, and take part in training for public authorities and training courses. The highest proportion of people in training courses was $30.9 \%$ of respondents, of which only $9.5 \%$ were women. The second highest group was vocational training in the National Training Register, $28.3 \%$ of the sample. A total of two women participated in this training group. In IT training, 74 people were enrolled, of which $77 \%$ were women. In terms of the proportion of participants in a given training group, women were the second most common in foreign language training, with $72.2 \%$ of participants in English being women. In general, the number of participants in English training was not dominated by the sample, with a total of 18 participants trained by employers. The total of 56 persons participated in authority training, mostly for driver and transport jobs. Only men participated in these training courses. Those with tertiary education were mostly enrolled in training and IT courses, while those with vocational and general education were enrolled in vocational courses.

The completion rate of on-the-job training is shown by the fact that $97.6 \%$ of respondents successfully completed all training courses. The 9 persons who failed to complete the training were due to the coronavirus epidemic. Among those who successfully completed the training, $26.5 \%$ of the respondents had an increase in income. The increase in income was most pronounced for men, with $32.9 \%$ of participants seeing an increase in their wages, compared to only $7.2 \%$ of women. The increase in income was most marked among those with vocational education and a school leaving certificate, but $25 \%$ of those with primary education increased their monthly income (Figure 6).

When asking participants about further learning, $84.9 \%$ of respondents said that if they had the opportunity to take part in future training provided by employer, they would use the opportunity, as $95.7 \%$ of them could use the new knowledge in their daily work. Training courses included communication, conflict management, sensitivity training, stress management, selfawareness, and coach training. These training courses were mostly attended by employees in customer service, call centre, and management positions. The highest proportion of participants was able to benefit from these trainings in their daily work. The majority of participants in the National Training Register training courses moved into a new job and thus nominally increased their 


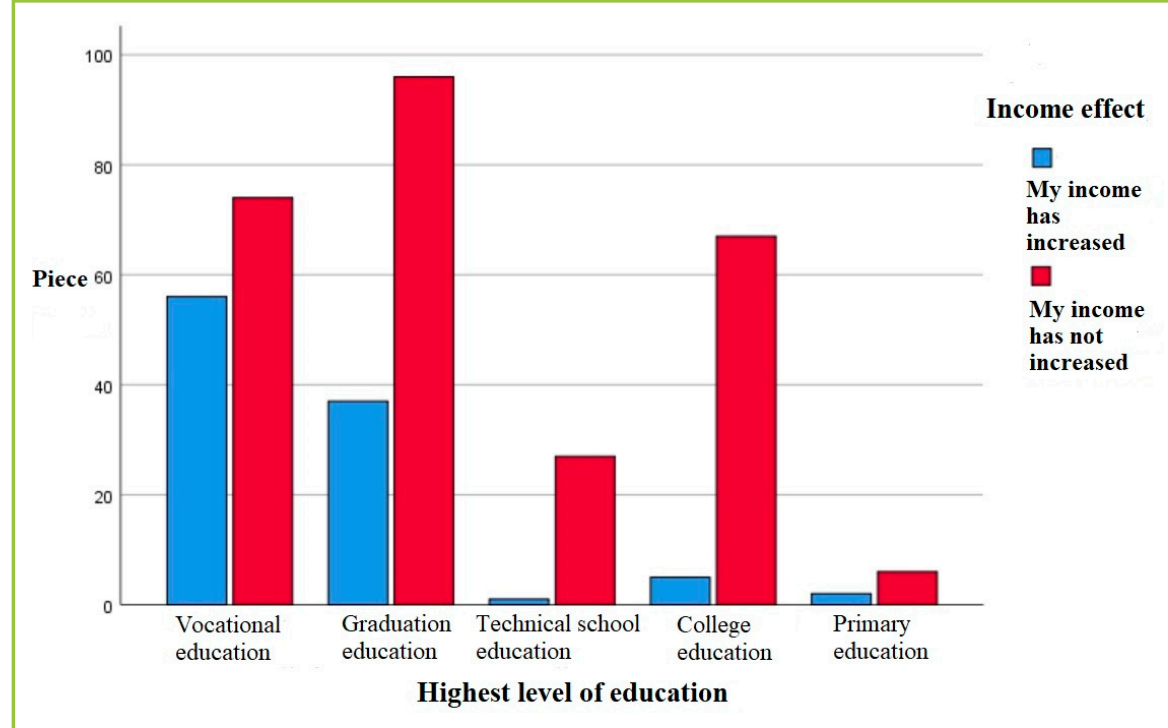

Figure 6 Examining the relationship between highest educational attainment and income growth Source: own design based on questionnaire survey (2021)

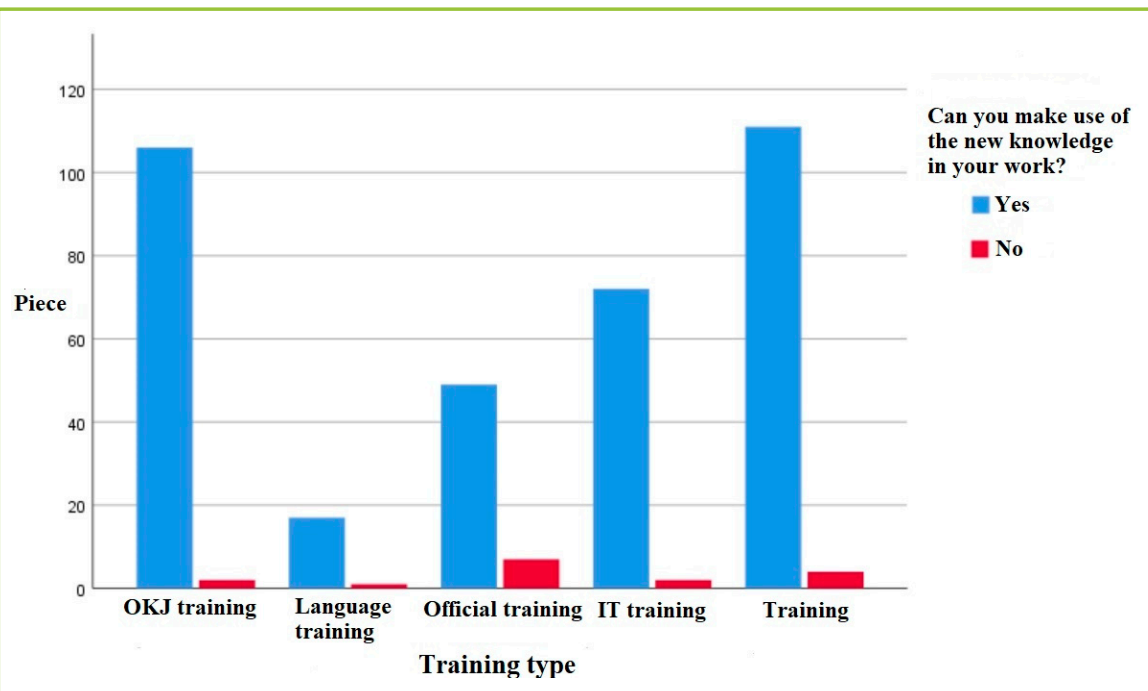

Figure 7 Examining the relationship between type of training and usefulness in everyday work Source: own design based on questionnaire survey (2021)

income. The vocational training also had a good impact on their work and they were able to make good use of it in their daily lives. Among the training courses that were not useful in everyday life, training for public authorities was the most frequently mentioned, which is not surprising, as it does not help and does not generally impart new skills, but is mandatory training for the job, which needs to be renewed every two years (Figure 7).

A strong correlation was observed between the usefulness of training and income growth. $98 \%$ of those whose income increased were able to make use of the new skills acquired.

\section{Conclusions}

In the framework of on-the-job trainings surveyed mainly men were trained in the Borsod-AbaújZemplén County. The majority of the employees trained had at least secondary education, with only a small number of people with primary education, although the inclusion of people with low education levels in training courses was an additional factor in the evaluation of applications. There was not one person in the sample who had not completed primary education. Employers give preference for their employees training courses and vocational qualifications, with the lowest number of people enrolled in language courses, due to the maximisation of foreign language courses in the tender. Drop-outs from training were almost non-existent, with the only dropouts being due to the coronavirus epidemic.

Workers perceived that their job position had increased, that their jobs had been consolidated thanks to the training and that they would take part in further training. Most took the training they wanted to take and would have done so without the employer's enrolment. Those who successfully completed the training were able to use the new knowledge in their daily work, and this is particularly true for vocational training.

Almost a third of those who received training reported an increase in their income as a result of the training. The biggest risk of onthe-job training is that the workforce trained by the company is seduced by a competing company (Sebők, 2016). Of course, the companies organising the training may try to keep workers by raising their wages.

A low proportion of respondents were managers, which is due to the wage maximum required in the tender, and also due to the fact that the company owners want to train their lower educated workers, who can be promoted to middle management status in the future.

The idea of lifelong learning has been successfully integrated by the applicant companies, as the employees involved in the training would continue to participate in the training, even at their own expense.

\section{Acknowledgement}

This study was "Supported by the ÚNKP-21-3. New National Excellence Program of the Ministry for Innovation and Technology from the source of the National Research, Development and Innovation Fund."

\section{References}

Berg, J. (Ed.) 2015. Labour Markets, Institutions and Inequality - Building Just Societies in the $21^{\text {tt }}$ Century. Edward Elgar Publishing, 2015, $432 \mathrm{p}$. ISBN 9781784712099

Borbély-Pecze, T. B. - Fazakas, I. 2019. Pályabolyongások Pályaorientációról a Szakképzés 4.0 stratégia kapcsán. In Új Pedagógiai Szemle, 2015, no. 7-8, pp. 95-106.

Farjad, S. 2012. The Evaluation Effectiveness of Training Courses in University by Kirkpatrick Model. In Procedia - Social and Behavioral Sciences, 2012, no. 46, pp. 2837-2841.

Farkas, É. 2014. A felnőttképzés finanszírozása: hazai folyamatok, nemzetközi trendek In: Henczi, Lajos (szerk.) A szak- és felnőttképzés-szervezés gyakorlata Budapest, Magyarország: RAABE Tanácsadó és Kiadó Kft, 2014, pp. 1-37. 
Goldstein, I. L. - Ford, K. 2002. Training in Organizations: Needs assessment, Development and Evaluation. Belmont: Wadsworth, 2002.

Hirschi, A. 2011. Effects of Orientations to Happiness on Vocational Identity Achievement. In The Carreer Development Quarterly, vol. 59, 2011, no. 4, pp. 345-366.

Horváth, Zs. 2018. Training for self-employment and active citizenship to achieve life satisfaction. In Képzés és Gyakorlat: Training and Practice, vol. 16, 2018, no. 2, pp. 77-84.

https://www.palyazat.gov.hu/ginop-615-17-munkahelyi-kpzsek-tmogatsanagyvllalatok-munkavllali-szmra

https://www.palyazat.gov.hu/ginop-616-17-munkahelyi-kpzsek-tmogatsa-mikro-kis-skzpvllalatok-munkavllali-szmra

Karlovitz, J. T. - Micheller, M. 2007. Felnőttképzésben alkalmazott oktatási módszerek Békés megyei oktatási vállalkozások körében. In Micheller, M. (szerk.), Kőrös Tanulmányok. Békéscsaba: Tessedik Sámuel Főiskola Gazdasági Főiskolai Kar, 2007, pp. $119-130$.

Kárpáti-Daróczi, J. 2020. Marginalizálódott rétegek oktatása-képzése a munkaalapú társadalomban. In: Torgyik, J. (szerk.) Társadalmi felelősség és szociális gondolkodás, Grosspetersdorf, Ausztria : Sozial und Wirtschafts Forschungsgruppe, 2020, pp. $125-129$.

Kiss, ZS. - Pirohov-Tóth, B. 2020. A családi háttér és a munkaerō-piaci sikeresség összefüggései. In International Journal of Engineering and Management Sciences, vol. 5, 2020, no. 3, pp. 131-141.

Márkus, E. 2016. Az általános célú felnőttképzés a statisztikák tükrében (OSAP 1665) In: Magyar, N. - és, Oktatáskutatók, E. (szerk.) A tanulás új útjai: HuCER 2016: absztrakt kötet Kaposvár, Magyarország : Magyar Nevelés- és Oktatáskutatók Egyesülete (HERA), 2016, $198 \mathrm{p}$.
Matiscsákné Lizák, M. 2012. Emberierőforrás gazdálkodás. Budapest : Complex Kiadó, 2012.

Novoszath, P. 2019. History of the Creation of Hungary's Unified Public Employment Program and Its Main Characteristics. In Urban Studies and Public Administration, vol. 1, 2019, no. 2, pp. 328-354.

Petty, T. - Thomas, C. 2014. Approaches to a Successful Adult Education Program. In College Student Journal, vol. 48, 2014, no. 3, pp. 473-480.

Polónyi, I. 2004. A vállalatok képzési politikájának néhány jellemzője I. In Munkaügyi Szemle, 2004, no. 3, pp. 25-30.

Sebők, M. 2016. Munkaerő-piaci mobilitás Magyarországon. Edge 2020 Kiadó, Budapest, 2016, $189 \mathrm{p}$.

Vámosi, Z. 2005. Humán erőforrás menedzsment. Budapest: LSI Oktatóközpont, 2005.

Varga, J. 1998. Oktatás-gazdaságtan Budapest, Magyarország: Közgazdasági Szemle Alapítvány, 1998, 162 p. ISBN 9630497921.

Vaszari, T. 2016. A vezetőképzések szerepe a gazdasági versenyképességben. In Vezetéstudomány/Budapest Management Review, vol. 47, 2016, no. 7, pp. 54-63.

\section{Contacts address}

Barbara Le-Dai, Hungarian University of Agriculture and Life Sciences, Mátrai út 36, 3200 Gyöngyös, e-mail: ledai.barbara@gmail.com 